\title{
UBE2T wt Allele
}

National Cancer Institute

\section{Source}

National Cancer Institute. UBE2T wt Allele. NCI Thesaurus. Code C131523.

Human UBE2T wild-type allele is located in the vicinity of $1 \mathrm{q} 32.1$ and is approximately 10 $\mathrm{kb}$ in length. This allele, which encodes ubiquitin-conjug ating enzyme E2 T protein, is involved in both protein ubiquitination and DNA repair. Mutation of the gene is associated with Fanconi anemia complementation group T. 